\title{
Drop spectrum in backpack sprayers in scarlet eggplant (Solanum aethiopicum)
}

Leonardo Carnevale Coelho ${ }^{1}$, Túlio de Almeida Machado ${ }^{2}$, Anderson Gomide Costa ${ }^{3}$, Elton Fialho dos Reis ${ }^{4}$, Cristiane Fernandes Lisboa $^{5}$

${ }^{1}$ Empresa de Assistência Técnica e Extensão Rural do Estado de Minas Gerais - Emater-MG. ${ }^{2}$ Instituto Federal Goiano IF Goiano, Campus Morrinhos. ${ }^{3}$ Universidade Federal Rural do Rio de Janeiro - UFRRJ, RJ. ${ }^{4}$ Universidade Estadual de Goiás - UEG, GO. ${ }^{5}$ Universidade Federal Rural da Amazônia - UFRA

\section{Abstract}

The use of manual backpack sprayers is common on rural properties for the application of phytosanitary products with different types of nozzles. The aim of the study was to evaluate the drop spectrum in the spray solution on scarlet eggplant crop. The study was conducted in a randomized block design (RBD) with a $2 \times 3$ factorial scheme, consisting of two working pressures 15 and $45 \mathrm{Psi}$, and three spray nozzles with four blocks. For the acquisition of information, hydrosensitive papers were used, which later had their images digitized and analyzed by the Gotas ${ }^{\circledR}$ software. The following values were extracted: number of drops, dispersion, applied volume, coverage and volumetric mean diameter (VMD). Then, the values found were subjected to analysis of variance and, according to significance, were compared by Tukey test at $5 \%$ probability level. For each factor, separately, the coefficients of variation were analyzed and then an analysis of the correlation between these factors was performed. The highest pressure produced the greatest number of drops and application coverage. Coverage was also the best at this pressure, which led to the highest coverage percentage.

Keywords: spray nozzles; spray pressures; quality of application.

\section{Espectro de gotas em pulverização costal na cultura do jiló (Solanum aethiopicum)}

\section{Resumo}

O uso de pulverizadores costais manuais é comum nas propriedades rurais para a aplicação de produtos fitossanitários com diferentes tipos de pontas. O objetivo do estudo foi avaliar o espectro de gotas em caldas de pulverização na cultura do jiloeiro. $O$ estudo foi em um delineamento em blocos casualizados (DBC) com esquema fatorial 2x3, constituído de duas pressões de trabalho 15 e 45 Psi, e três pontas de pulverização com quatro blocos. Para a aquisição das informações foram utilizados papéis hidrossensíveis que, posteriormente, tiveram suas imagens digitalizadase analisadas pelo software Gotas ${ }^{\circledR}$. Foram extraídos valores de: número de gotas, dispersão, volume aplicado, cobertura e DMV. Em seguida, os valores encontrados foram submetidos a análise de variância e, conforme a significância, foram comparados pelo teste de Tukey a $5 \%$ de probabilidade. Foram avaliados, para cada fator, separadamente, os coeficientes de variação e depois uma análise de correlação entre esses fatores. A maior pressão produziu o maior número de gotas e cobertura de aplicação. A cobertura também foi a melhor nessa pressão apresentando maior percentual de cobertura.

Palavras-chave: pontas de pulverização; pressões de pulverização; qualidade de aplicação.

\section{Introduction}

In Brazil in 2020, there were reductions in cultivated area of $5.7 \%$ for winter vegetables and $2.6 \%$ for summer vegetables. For 2021, the sector is expected to resume its growth to compensate for the decrease of the previous year (HF BRASIL, 2020).

Among the vegetables, scarlet eggplant (Solanum aethiopicum) is an annual crop native to Africa, belonging to the Solanaceae family 
(ALCÂNTARA; PORTO, 2019). Harvest begins between 80 and 100 days after sowing, with usually two weekly harvests, and can extend over a period of 3 to 5 months; it is a tropical fruit of great acceptance in the Brazilian market, whose planting area has been progressively increased in recent years (ALVES et al., 2012).

Despite being one of the most rustic species of the Solanaceae family, scarlet eggplant crop is subject to diseases, especially rot, which can cause considerable losses or compromise the quality of the product (PINHEIRO et al., 2015). Mostly, the control of its pathologies is carried out chemically through the application of phytosanitary products.

In order to make an assertive recommendation of application, it is necessary to take into account the crop cycle, its development stage, leaf area index (LAI), architecture and distribution of leaves in the canopy, besides the positioning of the damaging agent in the plant (ZANON et al., 2016).

One of the most important factors is to achieve a uniform spray with distribution throughout the field and also in the correct dosage, being complemented and with minimal product losses due to spray drift (DE COCK et al., 2017).

Spray nozzles are considered components of a sprayer, being responsible for breaking drops of different diameters (MATTHEWS et al., 2016). They directly influence spray distribution (FORNEY et al., 2017) and affect the effectiveness and penetration of the target in the crop canopy (CREECH et al., 2018; NEGRISOLI et al., 2019; SHARPE et al., 2017).

Fan nozzles are widely used in Brazil with classes for varied chemical applications and different crop alternatives (CHECHETTO et al., 2017). The performance of spray nozzles may vary according to the conditions to which they are subjected, with variations in the quality of application and, consequently, in the drop spectrum.

The use of flat jet nozzles with enlarged pressure range allows the formation of a population of drops with different characteristics, since working pressures between 100 and 130 $\mathrm{kPa}$ produce thicker drops, which are resistant to drift and suitable for the application of systemic herbicides. On the other hand, the operation at pressures close to $400 \mathrm{kPa}$ generates thinner drops, providing coverage of the target compatible with the requirements of contact herbicides, insecticides and fungicides (BOLLER; MACHRY, 2007).

Drop diameter directly affects the spray coverage and functionality of contact pesticides, as in the case of thinner drops, which have greater capacity to penetrate the inner regions and cover a larger surface (FERGUSON et al., 2016).

Thus, the aim of this study was to evaluate the drop spectrum in spray solutions with different spray nozzles and working pressures in manually actuated backpack sprayer.

\section{Material and methods}

The experiment was conducted at the Federal Institute of Goiás - Campus of Morrinhos, $\mathrm{GO}$, Brazil, with coordinates from $17^{\circ} 30^{\prime} 20^{\prime \prime}$ to $18^{\circ} 05^{\prime} 40^{\prime \prime}$ South latitude and from $48^{\circ} 41^{\prime} 08^{\prime \prime}$ to $49^{\circ} 27^{\prime} 34^{\prime \prime}$ West longitude, with an altitude of 771 $\mathrm{m}$ and with mild climate (humid tropical) (EMBRAPA, 2008). The topography is flat and the relief is undulating, with an average annual temperature of $20^{\circ} \mathrm{C}$ (IBGE, 2020).

The experiment was carried out in the field with scarlet eggplant crop, which had an approximate height of $1.25 \mathrm{~m}$, average canopy diameter of $1.8 \mathrm{~m}$ and at an average spacing of 2 $\mathrm{m}$ between plants. The crop was in a productive stage and had been planted 268 days before the study. Only water was used as an application solution.

At the time of application, temperature and relative humidity were measured using a portable thermo-hygro-anemometer, ICEL brand and HT-208 model, and the average results between the beginning and end of the application were $23{ }^{\circ} \mathrm{C}$ and $63 \%$, respectively, with an average wind speed of $1.6 \mathrm{~m} \mathrm{~s}^{-1}$. Spraying was performed using a manually actuated backpack sprayer with capacity of 20 liters.

Application speed was determined in three repetitions, by measuring the time to travel a distance of $10 \mathrm{~m}$, which resulted in an average speed of $0.42 \mathrm{~m} \mathrm{~s}^{-1}\left(1.5 \mathrm{~km} \mathrm{~h}^{-1}\right)$. The nozzles were kept, on average, at a distance of $0.8 \mathrm{~m}$ from the plant, thus having an application range of $1 \mathrm{~m}$. The jet was applied in the total area of the plant, perpendicularly to the soil surface. Only one nozzle was installed on the spray boom.

The experiment was conducted in a randomized block design (RBD) with treatments formed by a $2 \times 3$ factorial scheme, consisting of two pressures and three spray nozzles arranged in four blocks, totaling 24 plots. 
The sources of variation were determined by combining the use of two pressure control valves and three spray nozzles. The valves used were Jacto brand and Ecovalve model, with 103.421 kPa (15 Psi) and 310.264 kPa (45 Psi). The nozzles used are fan type, Magnojet brand and ADGA-02, AD-02-D and ADIA-02 models. These nozzles, according to the manufacturer, have the characteristics described in Table 1.

Table 1. Characteristics of the nozzles used

\begin{tabular}{|c|c|c|c|}
\hline Nozzle & Air induction & Pressure (kPa) & Flow rate $\left(\mathrm{L} \mathrm{min}^{-1}\right)$ \\
\hline AD5G-02 & No & 200 & 1.67 \\
\hline AD-02-D & No & 200 & 0.66 \\
\hline ADIA-02 & Yes & 200 & 0.67 \\
\hline
\end{tabular}

To collect the information on spraying, a SpinJet brand hydrosensitive paper with dimensions of $2.5 \mathrm{~cm} \times 7 \mathrm{~cm}$ was installed in each plot. They were distributed at $0.6 \mathrm{~m}$ inside the plot and at the height of the middle third of the plant (approximately $0.75 \mathrm{~m}$ from the soil surface).

In order to know the influence of leaf area on the crop, its values were estimated by the correlation between leaf width and leaf length, by means of a nondestructive method, based on linear measurements with graduated rulers (ASTEGIANO et al., 2001). Measurements of length (L) and width (W) were taken in 20 random leaves, collected in the three thirds of the plant (lower, middle and upper), in an area of $1 \mathrm{~m}^{2}$, counting the total number of leaves per plant. After the calculations, the Leaf Area Index (LAI) was determined and was equal to 0.64 .

After application, the hydrosensitive papers were collected and subsequently stored in paper envelopes for the acquisition of images. The images were acquired by scanning the hydrosensitive papers at a resolution of $600 \mathrm{dpi}$ using a scanner, Samsung brand and SCX-4200 model.

Before the analysis of the drop spectrum, the images were modified by Image J software and binarized in the $\mathrm{R}$ band for a better reading of the drop analysis software. Subsequently, they were analyzed by the Gotas ${ }^{\circledR}$ software (PESSOA;
CHAIM, 1999). The following values were extracted: density, dispersion, applied volume, coverage and Volumetric Mean Diameter (VMD).

The data were subjected to analysis of variance, at $5 \%$ significance level, and when their result was significant, the mean values were compared by Tukey test, at $5 \%$ probability level.

For each interaction between pressure and nozzle, separately, the coefficients of variation were evaluated and later an analysis of correlation between these factors was performed through a Pearson's correlation. These analyses were conducted using the free software ASSISTAT, beta version 7.7 (SILVA; AZEVEDO, 2016).

\section{Results and discussion}

Table 2 presents the $p_{\text {values }}$ and their significance for the factors pressure (P), spray nozzle $(\mathrm{N})$ and their interaction in terms of the means of the number of drops, dispersion, volume $\left(\mathrm{L} \mathrm{ha}^{-1}\right)$, coverage $(\%)$ and $\mathrm{VMD}(\mu \mathrm{m})$ for the evaluated drop spectrum. Differences were observed for pressure, number of drops, dispersion, volume and coverage. Spray nozzles caused difference only in VMD. In the interaction there was no difference, showing a behavior in which the levels of the factors act individually on the results of the variables. 
Table 2. Result of the analysis of variance in the evaluation of the effect of the factors: pressure, spray nozzle and their interaction in terms of the means of the number of drops, dispersion, volume, coverage and VMD

\begin{tabular}{|c|c|c|c|c|c|c|}
\hline & & № drops & Dispersion & $\begin{array}{l}\text { Volume } \\
\left(\mathrm{L} \mathrm{ha}^{-1}\right)\end{array}$ & $\begin{array}{c}\text { Coverage } \\
\text { (\%) }\end{array}$ & $\begin{array}{l}\text { VMD } \\
(\mu \mathrm{m})\end{array}$ \\
\hline sv & DF & $\mathbf{p}_{\text {value }}$ & $\mathbf{p}_{\text {value }}$ & $\mathbf{p}_{\text {value }}$ & $\mathbf{p}_{\text {value }}$ & $\mathbf{p}_{\text {value }}$ \\
\hline Working pressure & 1 & $0.01^{*}$ & $0.0081^{* *}$ & $0.0388^{*}$ & $0.0205^{*}$ & $0.1780^{\text {ns }}$ \\
\hline Spray nozzle & 2 & $0.11^{\mathrm{ns}}$ & $0.0744^{\mathrm{ns}}$ & $0.1509^{\text {ns }}$ & $0.1436^{\mathrm{ns}}$ & $0.0367^{*}$ \\
\hline Pressure*Nozzle & 2 & $0.74^{\mathrm{ns}}$ & $0.4238^{\text {ns }}$ & $0.9498^{\mathrm{ns}}$ & $0.9517^{\mathrm{ns}}$ & $0.5398^{\text {ns }}$ \\
\hline
\end{tabular}

** significant at $1 \%$ probability level $(p<.01) ;{ }^{*}$ significant at $5 \%$ probability level $(.01 \leq p<.05) ;{ }^{\text {ns }}$ not significant $(p \geq .05)$.

Figure 1 presents the images of the hydrosensitive papers in the treatments composed of the two pressures and the three evaluated nozzles. Later, Table 3 presents the values of the number of drops, dispersion, volume and coverage at the different pressure levels evaluated.

Figure 1. Labels of the evaluated treatments.

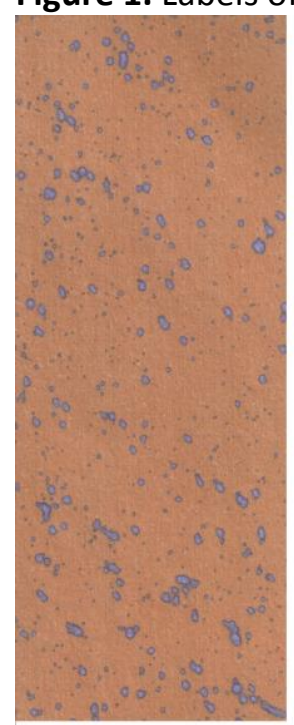

15 Psi

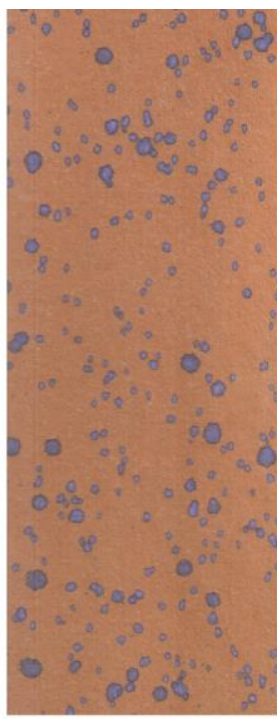

45 Psi

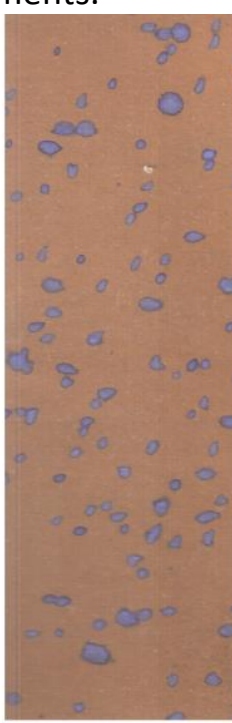

15 Psi

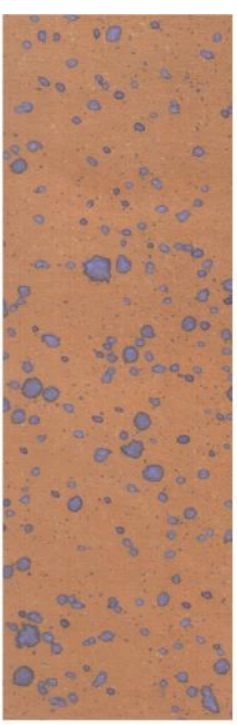

45 Psi

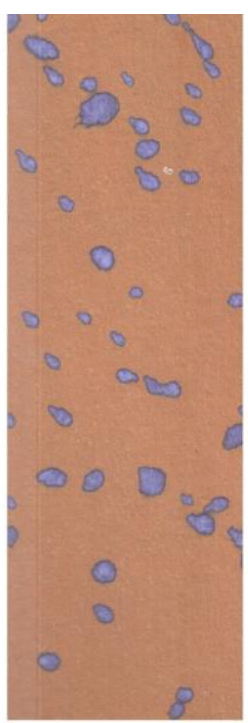

15 Psi

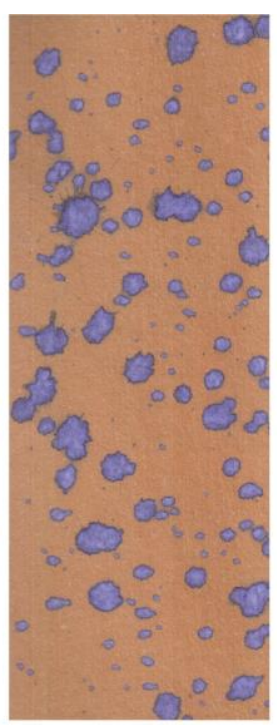

45 Psi

AD-02-D

ADIA-02

Table 3. Means for the number of drops, dispersion, volume and coverage at the pressures evaluated for the drop spectrum evaluated

\begin{tabular}{ccccc}
\hline $\begin{array}{c}\text { Pressure } \\
\text { (Psi) }\end{array}$ & No Drops & Dispersion & $\begin{array}{c}\text { Volume } \\
\left(\text { L ha }^{-1}\right)\end{array}$ & $\begin{array}{c}\text { Coverage } \\
\text { (\%) }\end{array}$ \\
\hline 15 & $436.88 \mathrm{~b}$ & $1.25 \mathrm{~b}$ & $2.30 \mathrm{~b}$ & $3.3 \mathrm{~b}$ \\
45 & $858.08 \mathrm{a}$ & $1.52 \mathrm{a}$ & $4.36 \mathrm{a}$ & $6.1 \mathrm{a}$ \\
\hline
\end{tabular}

Means followed by the same letter in the column do not differ by Tukey test at $5 \%$ probability level.

The pressure of 15 Psi differed statistically from $45 \mathrm{Psi}$, and the latter produced the largest number of drops because, as the pressure values are reduced, the diameter increases and, consequently, the number of drops read in the hydrosensitive paper in a given area is increased. This change occurred due to the use of a pressure regulator valve, not allowing the formation of very thin drops, which did not reach the target or were not read by the software. A higher number of drops, therefore, were found at a higher pressure.

When the destination of the phytosanitary product applied is the leaf mass of the crop or of weeds, it is recommended to avoid the application of very thick drops, as these have 
great potential for draining the solution applied to the soil. Drain losses are almost zero when working with drops with diameter of less than $500 \mu \mathrm{m}$ (MINGUELA, 2003).

Dispersion expresses the variation in drop diameter and is related to VMD; the higher its value, the greater the variation in drop diameter. Thus, the 45 Psi pressure led to the highest dispersion, with a significant difference between the pressures; therefore, the increase in pressure causes interference in the dispersion of the drops.

Coverage also showed a statistically different value, and at the 45 Psi pressure there was formation of a higher number of drops, which resulted in a higher percentage of coverage of the papers. Guler et al. (2012), studying different distances between nozzles and targets, state that in this situation spray coverage increased along with the values of application volume.

The results presented in Table 4 refer to the VMD of the drops deposited in the middle third of the scarlet eggplant, produced by the different spray nozzles.

Table 4. Means for VMD produced by the nozzles evaluated for the drop spectrum values evaluated

\begin{tabular}{cc}
\hline Nozzles & VMD \\
& $(\boldsymbol{\mu m})$ \\
\hline AD5G-02 & $419.50 \mathrm{~b}$ \\
AD-02-D & $566.12 \mathrm{ab}$ \\
ADIA-02 & $739.13 \mathrm{a}$ \\
\hline
\end{tabular}

Means followed by the same letter in the column do not differ statistically by Tukey test at $5 \%$ probability level.

The ADIA-02 nozzle with air induction and the AD5G-02 and AD-02-D nozzles without air induction are considered, in relation to their VMD, as producers of large drops, which are less subject to evaporation and drift. Drops smaller than $200 \mu \mathrm{m}$ are considered small and are easily dragged by drift and subject to evaporation, but provide greater coverage, higher drop density and greater capacity to penetrate in the canopy. Drops with diameters between 200 and $400 \mu \mathrm{m}$ are considered medium (RAMOS et al., 2004).

The ADIA-2 nozzle differed from the others for having air injection in the droplet, thus generating drops with a larger diameter. Thus, this increase in average drop diameter may pose a risk to safety in the application, especially in relation to draining, because drops with average diameter above $500 \mu \mathrm{m}$ should be avoided. Butts et al. (2019) state that spray nozzles with air induction show wide variation in spray pattern, especially at low working pressures, when compared to nozzles without air induction.

Thus, in cases where it is necessary to use this type of nozzle, care should be taken with product losses, avoiding environmental contamination due to the draining of the drops produced by this nozzle model.

Table 5 presents the values of the coefficient of variation (CV) for the variables number of drops, dispersion, volume, coverage and VMD after analysis of the hydrosensitive papers.

Table 5. Coefficient of variation for the variables number of drops, dispersion, volume, coverage and VMD for the evaluated spray treatments

\begin{tabular}{ccccccc}
\hline \multirow{2}{*}{ Treatments } & \multirow{2}{*}{ NS } & \multicolumn{5}{c}{ Coefficient of variation (\%) } \\
\cline { 3 - 7 } & & No Drops & Dispersion & Volume & Coverage & VMD \\
\hline P1N1 & 4 & 55.06 & 5.80 & 103.77 & 88.71 & 19.46 \\
P1N2 & 4 & 45.01 & 6.58 & 61.32 & 55.92 & 6.98 \\
P1N3 & 4 & 41.27 & 17.78 & 19.74 & 10.87 & 18.36 \\
P2N1 & 4 & 28.08 & 8.53 & 52.20 & 42.21 & 18.14 \\
P2N2 & 4 & 76.24 & 15.15 & 123.30 & 111.72 & 48.73 \\
P2N3 & 4 & 23.12 & 6.60 & 71.01 & 59.79 & 28.23 \\
\hline
\end{tabular}

P1: 15 Psi; P2: 45 Psi; N1: AD5G-02; N2: AD-02-D; N3: ADIA-02. NS: number of samples. 
The CVs of the variables analyzed for the treatments were mostly below $100 \%$, causing the drop spectrum values in the evaluated treatments not to be heterogenous. Among the variables analyzed, the values of dispersion were the ones that had the highest homogeneity, with some results below $10 \%$. On the other hand, the volume and coverage of application were the most heterogeneous variables, with values mostly above $50 \%$.

It can be noted that, among the combinations analyzed, P2B3 showed a better uniformity in the application, because it is known that the lower the $\mathrm{CV}$ recorded, the greater the accuracy in the flow rate distribution of the units evaluated.

These CV values can occur due to the use of the fan jet (vertically) and also because the spray boom was directed manually, in addition, logically, to the different working pressures.
In this context, Forney et al. (2017) demonstrated that the inclination of the spray nozzle in relation to the boom, as well as its height, boom height and working pressure, significantly affects the uniformity of spray distribution, regardless of the type of spray nozzle.

Massola et al. (2018) also state that controlled systems have characteristics that reduce this coefficient of variation, from the theoretical point of view, since other factors, such as climate and terrain, variation in boom height and relationship between spray nozzle spacing and plant significantly affect the uniformity of spray distribution in the field.

Pearson's correlation analysis among all variables under study is presented in Table 6 .

Table 6. Pearson's correlation for the variables number of drops, dispersion, volume, coverage and VMD for the evaluated drop spectrum

\begin{tabular}{cccccc}
\hline & No Drops & Dispersion & $\begin{array}{c}\text { Volume } \\
\left(\mathrm{L} \mathrm{ha}^{-1}\right)\end{array}$ & $\begin{array}{c}\text { Coverage } \\
(\%)\end{array}$ & $\begin{array}{c}\text { VMD } \\
(\boldsymbol{\mu m})\end{array}$ \\
\hline Drops & 1 & $0.7206^{* *}$ & $0.8102^{* *}$ & $0.8577^{* *}$ & $0.6882^{* *}$ \\
Dispersion & - & 1 & $0.5185^{* *}$ & $0.5563^{* *}$ & $0.3626^{\text {ns }}$ \\
Volume & - & - & 1 & $0.9955^{* *}$ & $0.8796^{* *}$ \\
Coverage & - & - & - & 1 & $0.8703^{* *}$ \\
VMD & - & - & - & - & 1 \\
\hline
\end{tabular}

${ }^{* *}$ significant at $1 \%$ probability level $(p<.01) ;{ }^{*}$ significant at $5 \%$ probability level $(.01 \leq p<.05) ;{ }^{\text {ns }}$ not significant $(p \geq .05)$.

Thus, a strong and positive correlation was observed between these variables: volume $x$ coverage (0.9956), and the variables that showed low correlation were dispersion $x$ volume (0.5185). With the results obtained in this study, it was found that, in general, the data of correlation between the parameters indicate robustness and safety for using the "hydrosensitive paper + software" set as an alternative way to evaluate spraying quality.

According to Cunha et al. (2010), if one intends to increase spraying quality, it is necessary to require more from the performance of the spray nozzles, particularly the homogeneity of the drop spectrum.

Therefore, it is always necessary to observe the operating condition, the nozzles and the pressure used for the application of phytosanitary products using backpack sprayers.

\section{Conclusion}

The pressures used modify the number of drops, dispersion, volume and application coverage.

Modification in VMD occurred only with the change of nozzles.

\section{References}

ALCÂNTARA, H. P.; PORTO, F. G. Influência de fertilizante foliar com aminoácidosna cultura do jiló. Brazilian Journal of Development, v. 5, n. 6, p. 5554-5563, 2019. https://doi.org/10.34117/bjdv5n6-087

ALVES, C. Z.; GODOY, A. R.; CANDIDO, A. C. D. S.; OLIVEIRA, N. C. D. Qualidade fisiológica de sementes de jiló pelo teste de envelhecimento acelerado. Ciência Rural, v. 42. n. 1, p. 58-63. 2012. 
https://doi.org/10.1590/S0103-

\section{$\underline{84782012000100010}$}

ASTEGIANO, E. D.; FAVARO, J. C.; BOUZO, C. A. Estimación del área foliar en distintos cultivares de tomate (Lycopersicon esculentum Mill.) utilizando medidas foliares lineales. Investigación Agraria: Producción y ProtecciónVegetales, v. 16, n. 2, p. 249-256, 2001.

BOLLER, W.; MACHRY, M. Efeito da pressão de trabalho e de modelos de pontas de pulverização sobre a eficiência de herbicida de contato em soja. Engenharia Agrícola, v. 27, n. 3, p. 722-727, $2007 . \quad$ https://doi.org/10.1590/S0100$\underline{69162007000400015}$

BUTTS, T. R.; LUCK, J. D.; FRITZ, B. K.; HOFFMAN, W. C.; KRUGER, G. R. Evaluation of spray pattern uniformity using three unique analyses as impacted by nozzle, pressure, and pulse-width modulation duty cycle. Pest Management Science, v. 75, n. 7, p. 1875-1886, 2019. https://doi.org/10.1002/ps.5352

CHECHETTO, R. G.; MOTA, A. A. B.; ANTUNIASSI, U. R.; CARVALHO, F. K.; VILELA, C. M.; ARRUDA, A.C. Caracterização da taxa de aplicação e pontas de pulverização utilizadas no estado do Mato Grosso. Magistra, v. 26, n. 1, p. 89-97, 2017.

CREECH, C.F.; HENRY, R.S.; HEWITT, A.J.; KRUGER, G.R.Herbicide spray penetration into corn and soybean canopies using air-induction nozzles and a drift control adjuvant. Weed Technology, v. 32, n.1, p.72-79, 2018. https://doi.org/10.1017/wet.2017.84

CUNHA, J. P. A. R.; BUENO, M. R.; FERREIRA, M. C. Espectro de gotas de pontas de pulverização com adjuvantes de uso agrícola. Planta Daninha, v. 28, n. especial, p. 1153-1158, 2010.

https://doi.org/10.1590/S0100-

$\underline{83582010000500023}$

DE COCK, N.; MASSINON, M.; SALAH, S.O.; LEBEAU, F. Investigation on optimal spray properties for ground based agricultural applications using deposition and retention models. Biosystems Engineering, v. 162, p. 99111, 2017. https://doi.org/10.1016/j.biosystemseng.2017.08 .001
EMBRAPA. Agricultura tropical: quatro décadas de inovações tecnológicas, institucionais e políticas. Brasília: Embrapa Informação Tecnológica, 2008. 704 p.

FERGUSON, J. C.; HEWITT, A. J.; O'DONNEL, C. C. Pressure, droplet size classification, and nozzle arrangement effects on coverage and droplet number density using air-inclusion dual fan nozzles for pesticide applications. Crop Protection, v. 89, n. 1, p. 231-238, 2016. https://doi.org/10.1016/j.cropro.2016.07.032

FORNEY, S. H.; LUCK, J. D.; KOCHER, M. F.; PITLA, $S$. K. Laboratory and full boom-based investigation of nozzle setup error effects on flow, pressure, and spray pattern distribution. Applied Engineering in Agriculture, v. 33, n. 5, p. 641-653, 2017.

https://doi.org/10.13031/aea.12043

GULER, H.; ZHU, H.; OZKAN, H.E.; LING, P. Characterization of hydraulic nozzles for droplet size and spray coverage. Atomization and Sprays, v. 22, n. 8, 2012.

https://doi.org/10.1615/AtomizSpr.2012006181

HF BRASIL. Anuário 2020-2021. v. 207, p. 12-16, 2020.

https://doi.org/10.1080/21645515.2020.1724732

IBGE. Estimativas da população residente no Brasil e unidades da federação com data de referência em 1o de julho de 2020. https://www.ibge.gov.br/estatisticas/sociais/pop ulacao/9103-estimativas-depopulacao.html?edicao $=28674 \& \mathrm{t}=$ resultados. Acesso em: 20 dez. 2020.

MASSOLA, M. P.; HOLTZ, V.; MARTINS, M. P. D. O.; UMBELINO, A. D. S.; REIS, E. F. Spray volume distribution pattern and droplet size spectrum from ceramic nozzles. Revista Brasileira de Engenharia Agrícola e Ambiental, v. 22, n. 11, p. 804-809, 2018. https://doi.org/10.1590/18071929/agriambi.v22n11p804-809

MATTHEWS, G. A.; BATEMAN, R.; MILLER, P. Métodos de aplicação de defensivos agrícolas. 4. ed. São Paulo: Andrei, 2016. 623 p.

MINGUELA, J. V. Aplicación de productos fitosanitarios, técnicas y equipos. Espanha: Ediciones Agrotécnicas, 2003. 389 p. 
NEGRISOLI, M. M.; RAETANO, C. G.; SOUZA, D. M.; SOUZA, F. M. S.; BERNARDES, L. M.; DEL BEM JÚNIOR, L.; RODRIGUES, D. M.; SARTORI, M. M. P. Performance of new flat fan nozzle design in spray deposition, penetration and control of soybean rust. European Journal of Plant Pathology, v. 155, n. 3, p. 755-767, 2019. https://doi.org/10.1007/s10658-019-01803-1

PESSOA, M. C. P. Y.; CHAIM, A. Programa computacional para estimativa de perdas de herbicidas aplicados por pulverização aérea. Pesquisa Agropecuária Brasileira, v. 34, n. 1, p. 45-56, 1999.

https://doi.org/10.1590/S0100-

$\underline{\text { 204X19990000100007 }}$

PINHEIRO, J. B.; PEREIRA, R. B.; FREITAS, R. A.; MELO, R. A. C. A cultura do jiló. Coleção plantar 75. 1. ed. Brasília: Embrapa Informação Tecnológica, 2015.

RAMOS, H.; SANTOS, J. M. F.; ARAÚJO, R. M.; BONACHELA, T. M. Manual de tecnologia de aplicação de produtos fitossanitários. Campinas: Línea Criativa, 2004. 50 p.

SHARPE, S. M.; BOYD, N. S.; DITTMAR, P. J.; MACDONALD, G. E.; DARNELL, R. L.; FERRELL, J. A. Spray penetration into a strawberry canopy as affected by canopy structure, nozzle type, and application volume. Weed Technology, v. 32, n. 1, p. 80-84, 2017.

https://doi.org/10.1017/wet.2017.86

SILVA, F. A. S.; AZEVEDO, C. A. V. The Assistat Software Version 7.7 and its use in the analysis of experimental data. African Journal of Agricultural Research, v. 11, n. 39, p. 3733-3740, 2016.

https://doi.org/10.5897/AJAR2016.11522

ZANON, A. J.; STRECK, N. A.; GRASSINI, P. Climate and management factors influence soybean yield potential in a subtropical environment. Agronomy Journal, v. 108 , n. 4, p. 1447-1454, 2016.

https://doi.org/10.2134/agronj2015.0535 